\title{
Preservation of Spatial Information
}

\author{
Göran Samuelsson \\ Mid Sweden University \\ 85170 Sundsvall, Sweden \\ goran.samuelsson@miun.se
}

\begin{abstract}
Summary
This article highlights the importance of preservation of spatial information, i.e. information clearly connected to a geographic position, regardless of whether it is a matter of GIS or CAD/BIM information. The author consider through his review and compilation of texts, interviews and workshops that we have existing tools for appraisal/selection, metadata and preservation formats that with minor additions are fully useful for creating a reliable digital continuum. The future work consists of - appraisal/selection and preservation - of spatial information and is extensive, and therefore the author believes the work should be initiated with immediate effect.
\end{abstract}

Key words: Spatial information, preservation, BIM, GIS, Metadata

\section{Introduction and background}

As society grows more digital, and more and more of the necessary societal sectors become increasingly information-dense and dependent on information, it is more important than ever that research focuses on what is currently a vital part of all businesses: information. It would make sense to assume that in information society there is a strategy for long-term information preservation and future use. This applies to all societal sectors, but this article highlights its importance within the field of spatial information, i.e. information clearly connected to a geographic position, regardless of whether it is a matter of geographical information or $\mathrm{CAD}^{1} \mathrm{BIM}^{2}$ information. The work towards a more long-term preservation of spatial information is still in its infancy. Any difficulties are related to the complexity of the information; information objects often have multiple connections to other information, and there are frequently various types of file formats. Since the 1950s, international standards have been developed within the field of geographical information, which is what makes it possible to exchange geographical information today. For the past 20 years, several countries have increased their efforts and together developed business concepts,

\footnotetext{
${ }^{1}$ Computer-aided design (CAD) is the use of computer systems (or workstations) to aid in the creation, modification, analysis, or optimization of a design. In Narayan, K. Lalit (2008).

${ }^{2}$ BIM definitions in: Abbasnejad B, Moud H. 2013.
} 
INFuture2017: Integrating ICT in Society

information models, objects and formats for the transfer of geographical information. ${ }^{3}$ Today, Sweden has a national strategy for geographical information, the purpose of which is to increase and facilitate collaboration within the field of geographical information. ${ }^{4}$ In Europe, the strategy also includes the implementation of the EC directive geographical information infrastructure (INSPIRE), which is a European collaboration aiming to develop synchronized national geographical information. The directive was adopted in 2007, the aim of which was to develop a European geographical information infrastructure. It is expected to be completed by $2019 .^{5}$ Even if these discussions and projects are aiming for a synchronized management of geographical information, it is still a work in progress nationally and internationally. All businesses in all societal areas are struggling with the issue of a long-term strategy for the preservation of information supply over time. Similarly, the process of developing strategies for the coordination of $\mathrm{CAD} / \mathrm{BIM}$ greatly increased during the last 5 years. BIM comes from the world of $\mathrm{CAD}$, and is connected to the introduction of 3D technology. Since 2012 there is an ISO standard, or rather a technical specification ISO/TS 12911:2012 Framework for Building Information Modelling (BIM) guidance - which includes a definition of the framework for the development of guidance for building information modelling (BIM). The standard is applicable to the development of guidelines for the modelling of buildings and structures of all scales, for groups including several structures as well as single parts of a structure. ${ }^{6}$

BIM is a model that is not only used by architects and constructional engineers to draw buildings. It can also be used for all types of structures, i.e. also roads, bridges and all sorts of land. BIM can be used to digitally develop one or more virtual and precise models of an object. It can be used as a support through all design stages and facilitates analysis and control, compared to manual processes. When these computer-generated models are complete, they include the exact geometry and information needed for design, production and purchase activities, through which the building comes into being. But the important part is really the information - the creation of a shared information model and a set of rules and regulations for the exchange of the model or parts of it. Selected parts of this information will accompany the object's management period for perhaps hundreds of years. In the US, home of what is perhaps the most developed construction industry, more than 70 percent of companies were already using BIM by $2012 .^{7}$ Strongly contributing to this interest is that, basically, everyone prof-

\footnotetext{
${ }^{3} \mathrm{http}$ //e2.relationbrand.com/stanli/_Nyhetsbrev-Nyhetsbrev_Nr_7_Oktober_2004/mail.html

${ }^{4}$ https://www.geodata.se/upload/dokument/strategi/geodatastrategi_2012.pdf. Retrieved 2017-03-11

${ }^{5}$ Bartha, G., \& Kocsis, S. 2011.

${ }^{6}$ Keenliside, S., \& Beange, M. 2016.

${ }^{7}$ Dodge Data \& Analytics, 2013
} 
G. Samuelsson, Preservation of spatial information

its from its introduction - public administration as well as the construction industry. In England, the government expects a 20-30 percent reduction of administration costs for buildings as a result. ${ }^{8}$ All over the world efforts have increased, and a number of national strategies have been developed. ${ }^{9}$ In the last 10 years, a number of projects world-wide have dealt with the issue of preservation, but it has not had any profound effect on everyday work in most areas of business. $^{10}$

\section{Purpose}

An overall aim of this article is to compile a state of the art of the knowledge we have, for further work within the ISERV-project11 and the subproject that studies the management of information in large infrastructure projects (road, rail, bridges, etc.). Specifically, this article will contribute with knowledge of and answers to the following questions:

- What principles of appraisal and selection are in place?

- What preservation formats are available for information objects and metadata?

At the same time, the result will help to develop a digital continuity model for managing spatial data in Sweden over time.

\section{Problems}

Currently, management of spatial information is an important part in a large number of businesses both producing and administrating information. It is a matter of databases that are purely spatial that are used in connection which all types of planning - in centralized management, energy, environment, town planning, school, care, etc. All organizations dealing with location-bound infrastructure, service and care in e.g. a municipal area need access to spatial information. But there are also many administrations who produce a great deal of

\footnotetext{
8 Ministry of Business, Innovation and Employment (MBIE), Building and Construction Productivity Partnership. http://www.buildingvalue.co.nz/sites/default/files/Productivity-Benefitsof-BIM.pdf. Retrieved 2016-12-10

9 New Zealand issued a national handbook in BIM in summer 2014; Australia 2012, buildingSMART Australasia, http://buildingsmart.org.au/advocacy/the-national-bim-initiativenbi/\#.WR_8_VPyjGI. Retrieved 2017-03-10

${ }^{10}$ Shaon, A et al (2011)

${ }^{11}$ The purpose of the ISERV-project is to develop prerequisites of the development of e-services and archival practices. The project is coordinated by a research group at Mid Sweden University and will also be carried out with participants of the Västernorrland region The project focuses on the capturing, managing and reuse of information within organizations. https://www.miun.se/ iserv/.
} 
data - data that then remains on respective administration. ${ }^{12}$ This means that the quality and format of the spatial information could vary. Because the technical administrations/functions of an authority have been early adopters of the digital tools, processing has often been digital for decades, while the formal decision documents have been printed and archived. For the last few years, some authorities have also expanded functionality and added the option of an e-archive. There is frequently a connection to a business system. Because few authorities have developed central e-archive solutions, it means that the authorities are running a risk of major interoperability problems in the future, as well as difficulties developing integrated and complete analysis and planning based on the information the authority as a whole has at its disposal. In a study, we have highlighted the problem areas that the authorities consider most urgent to deal with when it comes to spatial information:

- Lack of general coordination - fragmented and inaccessible information making any attempt of a comprehensive analysis difficult.

- Lack of reliable metadata and "working databases" that can sometimes be a cause for uncertainty and/or situations of legal doubt, where information on paper and digital material has not been synchronized.

- Lack of long-term preservation strategies. The growing volumes of spatial information require carefully prepared decisions in terms of what to preserve and how it should be preserved.

- Lack of guidelines for which information objects/storages that must, should, or can be preserved - suggestions for selection and priority are also connected to the development of specification for the information package arranged by the National Archives (so-called FGS).

- Inadequate information models that also include aspects of preservation (and information security aspects) within the field of spatial information.

- Lack of appropriate format for the long-term information supply. ${ }^{13}$

The lack of general strategies dealing with the long-term preservation of spatial information could have consequences directly affecting citizens' right to information in the long term. It also counteracts current investments in the digitalization of Swedish e-government data in general. Spatial information is an important part of the everyday work of government services - if it is not satisfactorily preserved it will affect other information collected. A very real example of this is when those in charge of spatial information at Stockholm County Council are no longer able to follow the current geographic growth of the city and analyse growth in connection to the health of the citizens - there is no information for the last $30-40$ years. ${ }^{14}$

\footnotetext{
${ }^{12}$ Inspire 2013: Infrastructure for Spatial Information in Europe Member State Report: Sweden, 2010-2012

${ }^{13}$ Samuelsson, G \& Svärd, P 2011

${ }^{14} \mathrm{http}$ ://folkhalsoguiden.se/amnesomraden/folkhalsoarbete/statistik/folkhalsa-pa-karta/ 108
} 
G. Samuelsson, Preservation of spatial information

\begin{abstract}
Method
Due to the nature of the study, methods with a mixed approach have been used, consisting of literature review, workshops, interviews and questionnaire. The literature review is used to map the research problems in previous studies/texts on GIS/BIM and information management. This review leads to the identification of the state of art and also eventually the research gap. In connection with formulating the problem, we carried out a questionnaire, primarily aimed at coordinators and producers of geographical information. We have also carried out a couple of workshops and semi-structure interviews of users of spatial information.
\end{abstract}

\title{
Result
}

In this section, we aim to compile the parts of the information on GIS/BIM and preservation, which we gathered through the literature review, the questionnaire and interviews / workshop. It can be considered an attempt to analyse and use what is already known to compile a basis for a continuity plan/model ${ }^{15}$ and a more operative checklist.

Standardization is always a work in progress, connected to the group working on all geographical information standards in ISO (ISO/TC 211 - Geographic information/Geomatics), aiming to develop a standard specifically for the preservation of geographical information "Standard for the Preservation of Geospatial Data and Metadata: ISO 19165". The group will have to carry on working for some time yet, before being able to deliver something substantial that can be used by any authority. While the standard will be adapted and based on the OAIS standard, it does not seem to take the records or business standard ISO 15489 , nor the metadata standard ISO 2308, into consideration. ${ }^{16}$

Our compilation has received the following subheadings:

- Appraisal, Retaining and Disposing of information

- Metadata

- File format/database format

\section{Appraisal, Retaining and Disposing of information}

Spatial information is information originating from some type of activity, which is why this type of material, in the formal archive sense, does not differ from social acts, building permits, municipality board minutes, etc. This means that just like with other information flows, it is necessary to map out the processes generating the information (See Fig 1). The easiest way of doing it is to follow activities in connection to a business analysis, as described in DIRKS (Design-

\footnotetext{
${ }^{15}$ MacLean, Margaret; Davis, Ben H (eds) 1999

${ }^{16}$ Kresse, W m.fl 2015.
} 
INFuture2017: Integrating ICT in Society

ing and Implementing Record Keeping Systems) and in ISO $15489 .{ }^{17}$ When it comes to information appraisal, "Guidance for process-oriented information mapping" by Swedish Civil Contingencies Agency (MSB) and the National Archives is a good support. ${ }^{18}$ Record planning includes a number of activities aimed at determining what business information and types of documents can be found in the organization's business processes - and how they should be handled during their lifetime. The latter is described in further detail in the final step Archival description, the content of which is primarily based on RA-FS 2008:4. ${ }^{19}$ The appraisal process takes its starting point in the Archives Act and its portal sections, the needs of your own business and an analysis of other societal needs. ${ }^{20}$

\begin{tabular}{|c|c|c|c|}
\hline Business analysis & $\begin{array}{l}\text { Information } \\
\text { Appraisal }\end{array}$ & Records planning & $\begin{array}{l}\text { Archival } \\
\text { description }\end{array}$ \\
\hline $\begin{array}{l}\text { Map and describe } \\
\text { processes }\end{array}$ & $\begin{array}{l}\text { Appraisal and } \\
\text { classification of } \\
\text { information }\end{array}$ & $\begin{array}{l}\text { Set up a } \\
\text { documentation plan }\end{array}$ & $\begin{array}{l}\text { Organize } \\
\text { archival description }\end{array}$ \\
\hline $\begin{array}{l}\text { Set up } \\
\text { classification structure }\end{array}$ & & $\begin{array}{l}\text { Decide types of } \\
\text { documents }\end{array}$ & $\begin{array}{l}\text { Take inventory of } \\
\text { information storage }\end{array}$ \\
\hline $\begin{array}{l}\text { Connect to system and } \\
\text { organization }\end{array}$ & & $\begin{array}{l}\text { Decide basic } \\
\text { metadata }\end{array}$ & $\begin{array}{l}\text { Present and describe } \\
\text { archives }\end{array}$ \\
\hline & & $\begin{array}{l}\text { Decide } \\
\text { metadata handling }\end{array}$ & \\
\hline
\end{tabular}

Figure 1. Business processes analysis

\section{Metadata}

For all types of information, the importance of metadata is increasing. The more frequent our migration, use and distribution of information, the more important accurate metadata becomes. In the archival context, the standards ISO 23081-

\footnotetext{
${ }^{17} \mathrm{https}: / /$ www.records.nsw.gov.au/recordkeeping/advice/dirks/methodology. See also Sahlén, T 2016.

${ }^{18}$ Riksarkivet 2012: Guidance for process-oriented information mapping. Retrieved 2017-05-01.

${ }^{19}$ National Archive Sweden (2008): Föreskrifter om verksamhetsbaserad arkivredovisning (RAFS 2008:4) https://riksarkivet.se/rafs?pdf=rafs/RA-FS\%202008-04.pdf. Retrieved 2017-04-30

20 The major laws and regulations that affect recordkeeping practice of Swedish public organisations are: The Freedom of the Press Act SFS 1949:105; The Public Access to Information and Secrecy Act SFS 2009:4001; The Administrative Procedure Act SFS 1986:223; The Archives Act SFS 1990:782; The Personal Data Act SFS 1998:204; The Public Sector Information Act SFS 2010:566; The National Archives Regulations 'RA-FS
} 
G. Samuelsson, Preservation of spatial information

1:2006 and ISO 23081-2:2009 emphasize connections and context, rather than more general standards, which also applies to spatial information. This means that to use the industry standard in an archival project on spatial information is desirable, which in our case agrees with the European Collaboration INSPIRE. The list below is a selection of the items found in the national metadata profile. $^{21}$

- Name - What is the official name of the document? map, photo of location 2012, building area etc.

- Description - A few lines describing the document, to help the receiver to interpret it. Do add a few descriptive pictures and links to any additional sources for those interested in finding out more if possible.

- Type - Is it e.g. lines, polygons, dot patterns, point clouds or text files?

- File format - E.g. SHP, DWG, TIFF, ICF .

- Collection method - What methods were used to put together the document? E.g. flight data, image interpretation, basic inventory etc.

- Quality - Describe the quality. How close are the points of measurement? Flying altitude? Sources of error?

- Geographical boundaries - Does it, for example, cover all of the municipality or $100 \mathrm{~m}$ on each side of a road?

- Other - A free text field to add that which doesn't quite fit elsewhere. Is there anything else the user needs to know? Maybe the eastern part of the area has not been updated the same way as the other parts? Maybe some objects have the incorrect height value $\mathrm{z}=0$, when really was no information about height? That is information that could be entered here.

- Urgency - When was it created? And for how long was the layer maintained/updated?

- Delivery date

- Person in charge - Name and contact information of the person in charge.

This list should be added with more traditional archival metadata describing the aim and context of the information created according to ISO 23081 and the framework found in PREMIS. ${ }^{22}$ Metadata Model ISO 23081 is for authoritative forms of transaction and has a recordkeeping focusses on the relationships between business activities, the people involved in them and the records that are produced from and by them. ${ }^{23} \mathrm{~A}$ proposal is that this model (Fig.2) gets an interchangeable optional part. The BIM models describe object and many infor-

\footnotetext{
${ }^{21}$ Swedish Standards Institute (SIS): Geodata - Nationell metadataprofil - Specifikation och vägledning -SS-EN ISO 19115:2005-geodata.se Version 3.1.1

$22 \mathrm{http}: / / \mathrm{www}$. loc.gov/standards/premis/. Preservation Metadata is the international standard for metadata to support the preservation of digital objects and ensure their long-term usability.

${ }^{23}$ Sue McKemmish, Glenda Acland, and Barbara Reed, (2000).
} 
mation flows today's have an information related to objects. Object should be able to replace or complement the People function.

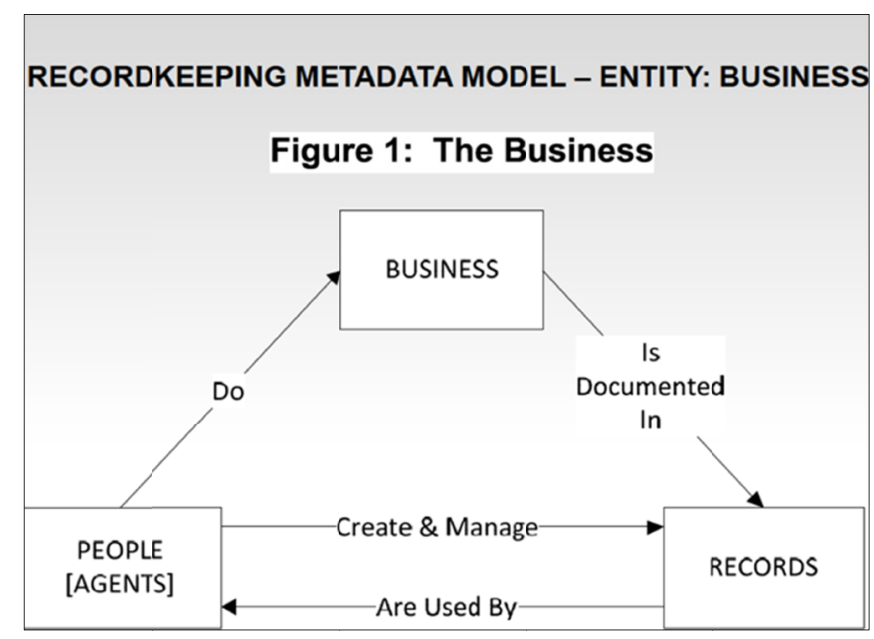

Figure 2. ISO 23081-1, Metadata for Records

\section{File format/database format}

Traditionally, Sweden has often been quite "strict" when talking about digital archives and file formats. Special archival formats should be used for this very purpose. It is often explicitly stated that no business formats should remain. In this case, I believe that we need to be more pragmatic and allow the most common business formats in the archive, at least for the foreseeable future. What is important is that the formats are accompanied by detailed documentation about the organization and structure of the format, and of course a reliable organization in terms of rights and regulations, defining who can collect and add information. However, major business actors such as ESRI, who deal with geographical information, have in the last few years started to understand the importance of being able to exchange information. They have developed guidance documents and instructions for their spatial information databases, describing extraction of datasets or entire databases in XML. ${ }^{24} \mathrm{We}$ have also noted that the Danish National Archives has introduced an updated version of their archive adaptation to the GML standard. ${ }^{25}$ A recommendation directly following the definition of which information to preserve, is to transfer the information in

\footnotetext{
${ }^{24} \mathrm{http} / /$ www.digitalpreservation.gov/formats/fdd/fdd000295.shtml\#sign

${ }^{25}$ GML is short for Geography Markup Language (GML); it is the XML structure that the Open Geospatial Consortium (OGC) has developed to describe geographical elements.

Danish National Archives 2016: https://www.sa.dk/wpcontent/uploads/2016/05/Geodata anvisning_2016.pdf
} 
G. Samuelsson, Preservation of spatial information

question to a more dedicated "archival server" and start working on developing a delivery/export feature, making constant transfer of spatial information in XML/GML possible from a number of different business processes to the e-archive/archival server. The Danish National Archives have also participated in the European Project E-AR, which have worked with preservation and use of geodata ${ }^{26}$ In the fall of 2017, the first more dedicated standard for the preservation of geodata will also be launched - ISO Standard for the Preservation of Geospatial Data and Metadata: ISO 19165. It will be synchronized with the OAIS model but will still require a lot of work of the business. When it comes to $\mathrm{CAD} / \mathrm{BIM}$ formats, there are still different voices - some advocate that you must have at least a few different formats depending on the information objects and purpose ${ }^{27}$. However, the dominant view is that the IFC ${ }^{28}$ format with continuous updating is more than enough to preserve information over time and create good conditions for interoperability both now and in the future. The project that worked the most with BIM and preservation is - DURAARK, which stands for "Durable Architectural Knowledge", which has produced a report on how to work with preservation and complex BIM-models. ${ }^{29}$

\section{Conclusion}

The interpretation, which can be drawn today, is that we, without major problems, should start the tangible work that is currently needed to be carried out with appraisal and preservation - of spatial information. This should be initiated with immediate effect. We have sufficient tools in the form of appraisal and business analysis and preservation format to begin a systematic archiving of spatial information.

\section{References}

Abbasnejad B, Moud H. (2013): BIM and basic challenges associated with its definitions, interpretations and expectations. Int J Eng Res Apps. 3:287-294.

Bartha, G., \& Kocsis, S. (2011). Standardization of geographic data: The european inspire directive. European Journal of Geography, 2(2), 79-89.

BIM Alliance Sweden (2012): Arkiveringsrekommendationer. Retrieved 2017-04-15

http://www.bimalliance.se/library/2445/del_3_bakgrund_preliminar_utgava_uppdaterad 20120602

E-Ark 2016: http://www.eark-project.com/29-user-stories-scenarios/122-pilot-5. Retrieved 201705-05

Evolve Consultancy: BIM Collaboration formats. http://www.evolve-consultancy.com/resource/ bim-brief/bim-collaboration-formats. Retrieved 2017-05-05.

${ }^{26}$ E-Ark 2016: http://www.eark-project.com/29-user-stories-scenarios/122-pilot-5

${ }^{27}$ Evolve Consultancy 201: BIM Collaboration formats. Retrieved 2017-05-05; Practical BIM http://practicalbim.blogspot.se/2013/06/ifc-what-is-it-good-for.html.

${ }^{28}$ buildingSMART: IFC Overview summary. Retrieved 2017-01-20. http://www.buildingsmarttech.org/specifications/ifc-overview. Business Collaborator Ltd; https://www.groupbc.com/blog/ 2015/02/10/open-bim/. BIM Alliance Sweden; http://www.bimalliance.se/soek/?q=arkivformat.

${ }^{29}$ Duraark (2015); Tamke, M. (2016) 
Dodge Data \& Analytics, 2013: "The Business Value of BIM in North America: Multi-Year Trend Analysis and User Ratings (2007-2012)," https://www.construction.com/aboutus/press/bim-adoption-expands-from-17-percent-in-2007-to-over-70-percent-in-2012.asp. Retrieved 2017-03-11

Duraark (2015): D7.3 Use case long term Archiving. Retrieved 2017-05-05

Inspire (2013): Infrastructure for Spatial Information in Europe Member State Report: Sweden, 2010-2012. Retrieved 2017-05-05.

InterPARES Trust (2016): Policies for recordkeeping and digital preservation. Recommendations for analysis and assessment services. Retrieved 2017-05-02

https://interparestrust.org/assets/public/dissemination/EU04_20160811_FinalReport.pdf.

ISO 19165 Standard for the Preservation of Geospatial Data and Metadata

ISO 23081-1 2006: Information and documentation - Records management processes - Metadata for records - Part 1: Principles

ISO 23081-2 2009: Information and documentation - Managing metadata for records - Part 2: Conceptual and implementation issues.

ISO/TS 12911:2012: Framework for building information modelling (BIM) guidance

ISO 19165 Standard for the Preservation of Geospatial Data and Metadata

ISO 15489-2 2001: Information and documentation - Records management - Part 2: Guidelines

Keenliside, S., \& Beange, M. (2016). A Comparative Analysis of the Complexities of Building

Information Model (ling) Guides to Support Standardization. International Journal of 3-D Information Modeling (IJ3DIM), 5(3), 18-30.

Kresse, W; Masó, J (2015): Development of an ISO-Standard for the Preservation of Geospatial Data and Metadata: ISO 19165. In Photogrammetrie - Fernerkundung - Geoinformation 2015(6):449-456

Library of Congress (2017): Sustainability of Digital Formats: Planning for Library of Congress Collections. ESRI Geodatabase XML. Retrieved 2017-05-12. https:/www.loc.gov/preservation/ digital/formats/fdd/fdd000295.shtml\#sign.

MacLean, Margaret; Davis, Ben H (eds) (1999): Time \& Bits: Managing Digital Continuity. Getty Publications. ISBN 0-89236-583-8.

McKemmish, S; Acland,G and Reed, B, (2000): Towards a Framework for Standardising Recordkeeping Metadata: The Australian Recordkeeping Metadata Schema. Monash University,http:/www.infotech.monash.edu.au/research/groups/rcrg/publications/framewrk.html. Retrieved 2017-03-15.

Ministry of Business, Innovation and Employment (MBIE), Building and Construction Productivity Partnership (2012): http://www.mbie.govt.nz/about/whats-happening/news/document-imagelibrary/nz-bim-productivity-benefits.pdf. Retrieved 2016-12-11.

Narayan, K. Lalit (2008): Computer Aided Design and Manufacturing. New Delhi: Prentice Hall of India. p. 3. ISBN 812033342X.

National Archives of Denmark (2016): Anvisning i aflevering af geodata til Rigsarkivet. https:/www.sa.dk/wp-content/uploads/2016/05/Geodata_anvisning_2016.pdf. Retrieved 2017-05-18

National Archives Sweden (2008): https://riksarkivet.se/rafs?pdf=rafs/RA-FS\%202008-04.pdf National Archives Sweden (2012): Guidance for process-oriented information mapping. Retrieved 2017-05-01

Sahlén, T (2016): Information management in the public and private sectors.

Shaon, A et al (2011) Long-term sustainability of spatial data infrastructures: a metadata framework and principles of geo-archiving. In Proceedings of the 8th International Conference on Preservation of Digital Objects (iPRES 2011).

Swedish Standards Institute (SIS) (2005): Geodata - Nationell metadataprofil - Specifikation och vägledning -SS-EN ISO 19115:2005-geodata.se Version 3.1.Retrieved 2017-04-11.

Samuelsson, G \& Svärd, P (2011): E-Government Developments and The Challenges of Managing Geodata. Linz : Trauner Druck GmbH \& Co KG (Schrifenreihe Informatik 37).

Tamke, M. (2016). Enabling BIM for the full Lifecycle of buildings. In no 3, Geospatial World.

114 